\title{
THE COMPETITIVENESS OF FERRY SHIPPING COMPANY IN INDONESIA
}

\author{
Solikin $^{1}$, H.M Thamrin ${ }^{2}$, Widodo ${ }^{3}$ \\ 1. STMT Trisakti, 2. STMT Trisakti, 3. STMT Trisakti \\ corresponding author: syfon_4@yahoo.com
}

\begin{abstract}
This research aims to investigate the effect of entrepreneurship and innovation in organization performance and the competitiveness of ferry shipping company in Indonesia commercial trajectory. The method of this research was a survey. There were 122 ships captains taken through random sampling. The data analysis used descriptive and inferential statistical analysis in structural equation modeling. The results shows that there are a significant direct effect of entrepreneurship in organization performance, a positive and significant direct effect of innovation in organization performance, a significant direct effect of organization performance in competitiveness company, a significant indirect effect of entrepreneurship competitiveness company mediated by organization performance, a significant indirect effect of innovation in competitiveness company mediated by organization performance.

Keywords: entrepreneurship, innovation, organization performance, and competitiveness company.
\end{abstract}

\section{Introduction}

Globalization has changed business in numerous sectors/fields including shipping activities and logistics. The changes imply the competition among corporations and companies massively. Only corporations or companies have high competitiveness can grow and develop while the corporations or companies have low or limited competitiveness have to survive or bankrupt. The ferry shipping companies encounter it, especially in Indonesia's main routes: Merak - Bakauheni, Kayangan - Pototano, Lembar - Padangbai, and Ketapang - Gilimanuk. Table 1.1 shows 42 ferries operating company in four main routes, 15 companies have one ferry, 11 companies have two ferries, 5 companies have three ferries, 2 companies have four ferries, and 2 companies have five ferries. In $83.3 \%$ companies only have one - five ferries. The condition of ferries is used for shipping is old. It is from 1970 until 1990. The condition indicates that the companies failed to rejuvenate their fleets as the indication of low company performance and low competitiveness. The conditions not only presents the phenomenon of 
shipping business concerns, but also can interfere with inter-island transportation and logistics activities that can give big impact to the socialeconomic community life. Moreover crossing ferries can disrupt business and activities of transporting or carrying goods/or passengers from one place to another place (Gunawan, 2015) that represent the series of consumers supply chain (Chopra \& Meindl, 2010).

Competitiveness is about learning how to work within established environment (Martinez \& Wolverton, 2009). Competitiveness also gives the advantage for company and competitors and additional value for consumers (Hutabarat \& Huseini (2012). Masyhudzulhak (2014) argued that the advantage of competitiveness gives the organization ability to manage carrying and absorption capacity of the company optimally. Barney \& Hesterly (2008) explained "in general, a firm has a competitive advantage when it is able to create more economic value than rival firms." Ireland, Hoskisson, and Hitt (2011) also stated, "a firm has a competitive advantage when it implements a strategy competitors that unable to duplicate or imitate." Watkins \& Verma (2007) identified 8 pillars of competitiveness. There are higher education and training, ability to absorb technology, ability to innovate, infrastructure, institutions, financial market sophistication, business sophistication, and macroeconomic stability.

Competitiveness can be affected by organization performance. Research by Yang (2013) proved that organization performance has an effect on competitiveness. The research was done in Taiwan with 163 respondents and analyzed with structural equation model (SEM)

Aggregate organization performance includes five managerial practices, there are organizational learning and change, communication, coordination, problem solving, and skills development (Minvielle et al, 2008). In the company context (Ross, Westerfield, \& Jordan (2008), company performance is a company's profitability or value. Fitzgerald et al. (in Atkinson \& Brown, 2011) developed an organization performance measurement model through six dimensions: (1) competitiveness: relative market share and sales growth, consumer-based measures; (2) financial 
performance: profitability, liquidity, capital structure, market ratios, (3) service quality: reliability, responsiveness, aesthetics/appearance, cleanliness/neatness, comfort, hospitality, communication, courtesy, competence, access, availability, security; (4) flexibility: volume of flexibility, speed in providing flexibility, flexibility specification, (5) resource utilization: productivity, efficiency; and (6) innovation: innovation process performance, individual innovator performance. It means that organization performance is a company's ability to produce results on target as measured by indicators: competitiveness, financial performance, service quality, flexibility, and resource utilization.

Thus it can be hypothesized that:

$\mathrm{H}_{1}$ : There is a direct effect of organization performance in competitiveness.

Organization performance can be influenced by entrepreneurship. The research by Wang (2008) in England and Rao (2012) India shows that entrepreneurship has an effect on business performance. Entrepreneurship is a dynamic process of gaining additional wealth (Hisrich, Peters \& Shepherd, 2008), with regard to change (Audertsch, in Affif, 2012), The state must prepare Human Resources as a business actor, with paradigms changing very quickly and sustainable innovation is a necessity, modern organizations should place employees as assets, this is a major issue that must be continuously developed (Fances Jorgensen, et all, 2009), a process undertaken to meet someone's needs and wants through innovation, regardless of the resources they control (Robbins \& Judge, 2013). Wirasasmita (in Suryana \& Bayu, 2010) stated that entrepreneurship and entrepreneur are the main factors of production which can mobilize and utilize other resources such as natural resources, capital and technology, to create wealth and prosperity through the creation of employment, income, and product needed by people. McClelland (in Suryana \& Bayu, 2010) divided entrepreneurial characteristics into six: (1) loving jobs with realistic risks; (2) working harder in tasks requiring mental ability; (3) not working harder for money; (4) wanting to work on situations providing opportunities 
for personal achievement; (5) showing better performance under conditions providing a true positive feedback; and (6) thinking for the future as well as the long-term plan. Thus it can be hypothesized that:

$\mathrm{H}_{2}$ : There is a direct effect of entrepreneurship on organization performance.

In addition, organization performance is also influenced by innovation. The research of Marques \& Ferreira (2009) in Portugal, Balan \& Lindsay (2010) in Australia, and Gunday, et al. (2011) in Turkey proved that innovation has an effect on company performance. Innovation is a process in which products, processes, materials, and services are developed and transferred to the appropriate markets (Rubenstein, in White \& Bruton, 2007). Other scholars define innovation as "the process of creating a commercial product from invention" (Ireland, Hoskisson \& Hitt, 2011). In addition to those definitions, Drucker, in Ireland, Hoskisson \& Hitt (2011) defined innovation as a special function of entrepreneurship, whether in an existing business, a public service institution, or a business recently started by individual. In relation to knowledge, Tidd and Bessant (2009) stated that innovation is creating new possibilities through a combination of different knowledge. According to Kleysen \& Street (2011), there are five indicators for measuring innovative behavior: (1) opportunity exploration, including paying attention to opportunity sources, finding opportunities for innovation, recognizing opportunities, and gathering information about opportunities; (2) generativity, including: generating ideas or solutions for opportunities, generating representations or opportunities categories, and generating associations and combinations of ideas and information; (3) informative investigations, including: formulating ideas and solutions, modeling ideas and solutions, evaluating ideas and solutions; (4) championing, including: mobilizing resources, persuading and influencing, encouraging and negotiating, challenging and taking risks; (5) application, including: implementing, modifying, and familiarizing. Thus it can be hypothesized that: $\mathrm{H}_{3}$ : There is a direct effect of innovation in organization performance. 
From the description above it stated that entrepreneurship and innovation directly affect organization performance, while organization performance affects competitiveness. Thus it can be hypothesized that:

$\mathrm{H}_{4}$ : There is an indirect effect of entrepreneurship in competitiveness with the mediation of organization performance.

$\mathrm{H}_{5}$ : There is an indirect effect of innovation in competitiveness with the mediation of organization performance.

\section{Method}

This research used survey method. The population was 175 captains and chief officers of the Ferry ships owned by 42 Ferry shipping companies operating in four commercial routes in Indonesia: Merak - Bakauheni, Kayangan - Pototano, Lembar - Padangbai, and Ketapang - Gilimanuk while the samples were 122 captains and chief officers taken from nonproportionate random sampling. The data collection used questionnaire instruments in the form of Likert scale. The validity and reliability showed 13 items of valid and reliable competitiveness questionnaires, 10 items of valid and reliable organization performance questionnaires, 11 items of valid and reliable entrepeneurship questionnaires, and 10 items of valid and reliable innovation questionnaires. The data obtained from these instruments were analyzed with Structural Equation Modelling (SEM) approach.

\section{Discussion and Result}

The results of statistical calculation using SEM approach processed by LISREL 8.80 program show the path coefficient and $t_{\text {value }}$ as follows. 


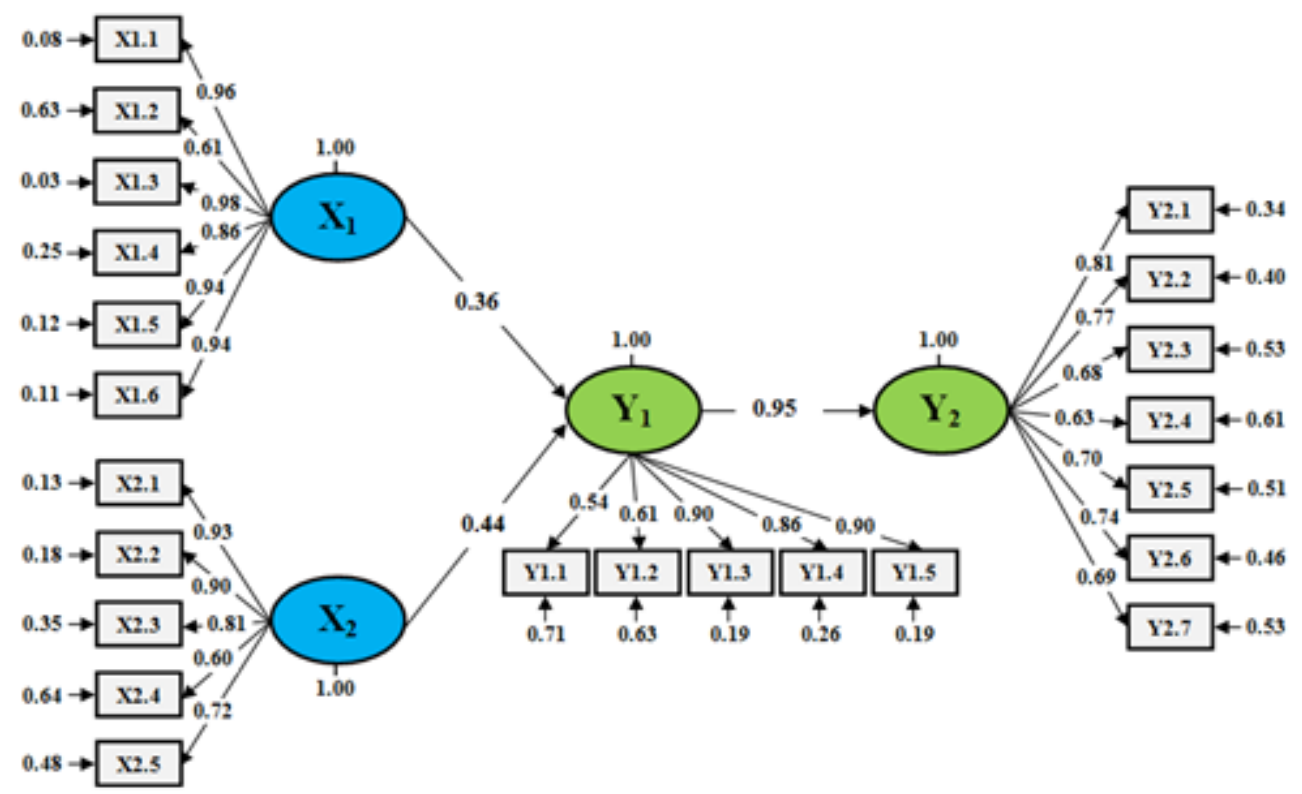

Figure 1

The Path Coefficient of the Effect of Entrepreneurship $\left(\mathbf{X}_{1}\right)$ and Innovation $\left(\mathbf{X}_{2}\right)$ on Organization Performance $\left(\mathbf{Y}_{1}\right)$ and Competitiveness $\left(\mathbf{Y}_{2}\right)$

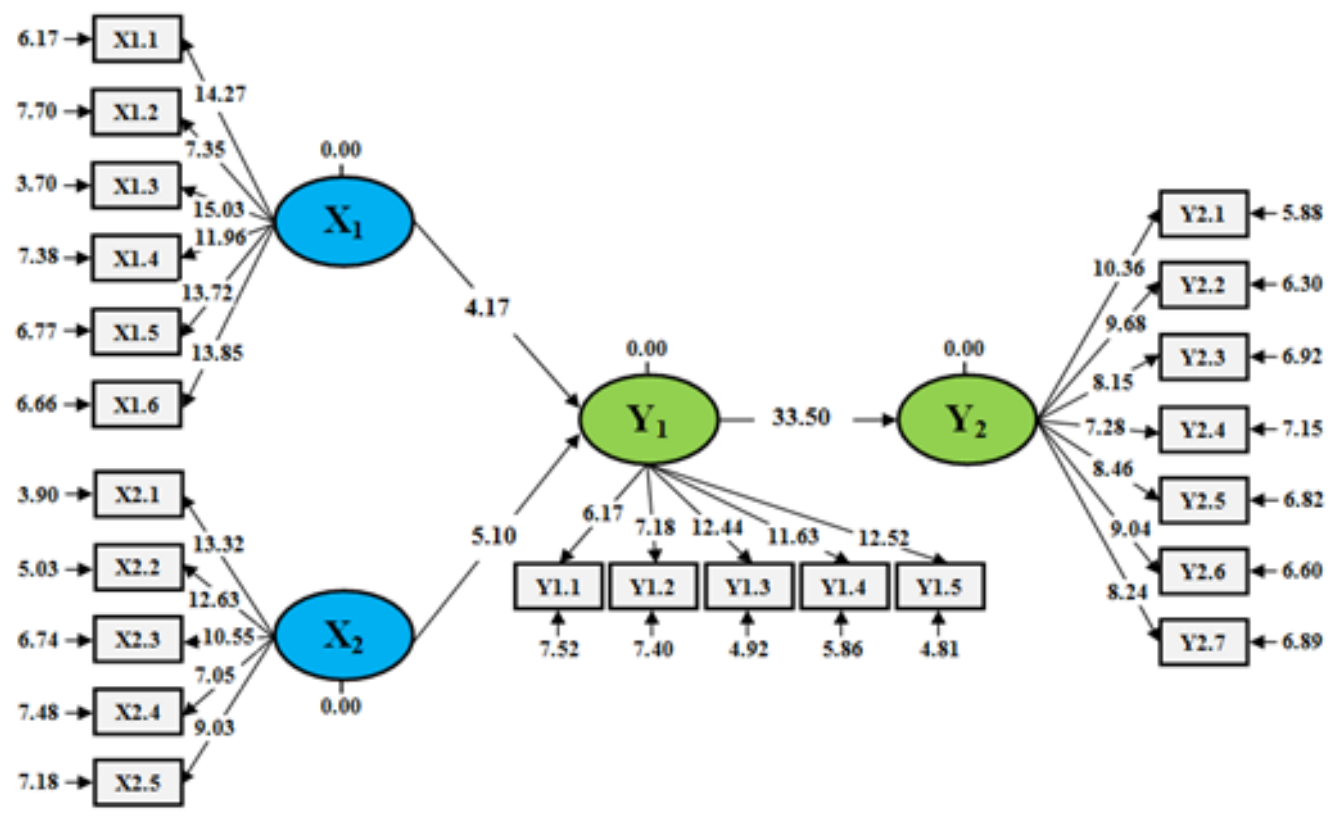

Figure 2

The $t_{\text {value }}$ of the Effect of Entrepreneurship $\left(\mathbf{X}_{1}\right)$ and Innovation $\left(\mathbf{X}_{2}\right)$ on Organization Performance $\left(\mathbf{Y}_{1}\right)$ and Competitiveness $\left(\mathbf{Y}_{2}\right)$

The resulting indexes to understand the suitability of the model can be seen in Table 1. 
Table 1 Model Suitability Testing

\begin{tabular}{|c|c|c|c|c|}
\hline No & Index & Standard Score & Score Obtained & Description \\
\hline 1 & $\mathrm{P}\left(\chi^{2}\right)$ & $>0.05$ & 0.028 & Not Fit \\
\hline 2 & RMSEA & $<0.08$ & 0.066 & Not Fit \\
\hline 3 & GFI & $>0.90$ & 0.97 & Good Fit \\
\hline 4 & AGFI & $>0.90$ & 0.86 & Not Fit \\
\hline 5 & NFI & $>0.90$ & 0.98 & Good Fit \\
\hline 6 & NNFI & $>0.90$ & 0.96 & Good Fit \\
\hline 7 & CFI & $>0.90$ & 0.99 & Good Fit \\
\hline 8 & IFI & $>0.90$ & 0.99 & Good Fit \\
\hline 9 & RFI & $>0.90$ & 0.94 & Good Fit \\
\hline
\end{tabular}

The result of model suitability test shows that from 9 indexes there are three indexes categorized as not suitable, which is $\mathrm{P}\left(\chi^{2}\right)$, RMSEA and AGFI while GFI, NFI, NNFI, CFI, IFI, and RFI are categorized as suitable. The results of this test show that more indexes are categorized as suitable, so it can be concluded that the empirical model of the effects of entrepreneurship, innovation and organization performance on competitiveness is suitable with its theoretical model.

The path coefficient result of the direct effect of entrepreneurship on organization performance is 0.36 while the $t_{\text {value }}$ score obtained is 4,17 , and the $t_{\text {table }}$ score at $\alpha=0.05$ is 1.97 . The score of $t_{\text {value }}>t_{\text {table, }}$, thus $\mathrm{H}_{1}$ is accepted, which means entrepreneurship has a positive and significant direct effect in organization performance. The results of this research empirically prove that entrepreneurship has a positive and highly significant direct effect on organization performance. It also proves that entrepreneurship has an important and vital role in determining the organization performance. Entrepreneurship is a dynamic process involving vision, changes, and creation and requiring energy and passion toward the formation of new ideas and creative solutions which can be manifested in loving jobs with realistic risks, working harder in tasks requiring mental ability, not working harder for money, wanting to work on situations providing opportunities for personal achievement, showing better performance in conditions providing positive 
feedback, and thinking for the future as well as the long-term plan. When they are obtained by the company's human resources, especially the leaders, it can encourage the improvement of the organization performance as a proof of the company's ability to achieve the target as reflected in: competitiveness, financial performance, service quality, flexibility, and resource utilization. The research of Wang (2008) and Rao (2012) also showed that entrepreneurship has a positive effect on business performance. Thus, these findings conform, support, and confirm the results of the previous research that entrepreneurship has a positive and significant direct effect on organization performance, especially ferry shipping companies in Indonesia.

The path coefficient calculation result of the direct effect of innovation in organization performance is 0.44 . While the $t_{\text {value }}$ obtained is 5.10 , and the $t_{\text {table }}$ score at $\alpha=0.05$ is 1.97 . The score of $t_{\text {value }}>t_{\text {table, }}$, thus $\mathrm{H}_{2}$ is accepted, which means innovation has a positive and significant direct effect on organization performance. The result of this research empirically proves that innovation has a positive and highly significant direct effect in organization performance. This indicates that innovation plays an important role in determining the organization performance. Innovation is an individual action directed toward generating, introducing or applying new and beneficial findings at every level of the organization as reflected in opportunity exploration, generativity, informative investigation, championing, and application. When these indicators are obtained by the company's human resources, in particular the leaders, it can encourage the improvement of the organization performance as a proof of the company's ability to achieve target through competitiveness, financial performance, service quality, flexibility, and resource utilization. The research results of Marques and Ferreira (2009), Gunday, et al. (2011), as well as Balan and Lindsay (2010) also stated that innovation has a significant effect in organization performance. Thus, the results of this research conform, support and confirm the results of previous research that innovation has a positive and significant direct effect on organization performance, especially Ferry shipping companies in Indonesia. 
From the calculation of the results, the path coefficient of the direct effect of organization performance in competitiveness is 0.95 . While the $t_{\text {value }}$ score obtained is 33.50 , and the $t_{\text {table }}$ score at $\alpha=0.05$ is 1.97 . The score of $t_{\text {obtained }}>t_{\text {table }}$, thus $\mathrm{H}_{3}$ is accepted, which means organization performance has a positive and significant direct effect on competitiveness. The result of this research empirically proves that organization performance has a direct positive and highly significant effect on company competitiveness. It indicates that organization performance is very important and vital to the competitiveness company. The organization performance reflects the company's ability to achieve target through competitiveness, financial performance, service quality, flexibility, and resource utilization. When these indicators are achieved and obtained optimally, it can encourage the competitiveness of the company as a prove of the company's ability to deliver more value to its services than its competitors and the value brings benefits to customers manifested in higher education and training, ability to absorb technology, ability to innovate, infrastructure, institutions, financial market sophistication, and business sophistication. The results of Yang (2013) research also showed that organization performance has an effect in competitiveness. Thus, the findings of this research conform, support and confirm the result of previous research that organization performance has a positive and significant direct effect on company competitiveness, especially Ferry shipping companies in Indonesia.

From the calculation results, the path coefficient of the indirect effect of entrepreneurship on competitiveness with the mediation of organization performance is 0,38 . While the $t_{\text {value }}$ score obtained is 4.13 , and the $t_{\text {table }}$ score at $\alpha=0.05$ is 1.97 . The score of $t_{\text {value }}>t_{\text {table, thus }} \mathrm{H}_{4}$ is accepted, which means entrepreneurship has a positive and significant indirect effect on competitiveness with the mediation of organization performance. The result of this research empirically proves that entrepreneurship has a positive and significant indirect effect on company competitiveness with the mediation of organization performance. It proves that entrepreneurship is important to determine competitiveness company with organization performance supports. 
These results are consistent with the direct effect of entrepreneurship in organization performance and organization performance in competitiveness company. Entrepreneurship is manifested in a dynamic process involving vision, changes, and creation and requiring energy and passion toward the formation of new ideas and creative solutions, and reflected in loving jobs with realistic risks, working harder in tasks requiring mental ability, not working harder for money, wanting to work in situations providing opportunities for personal achievement, showing better performance in conditions providing positive feedback, and thinking for the future as well as the long-term plan, this can drive the improvement of organization performance manifested in the ability of the company to achieve target achieved through competitiveness, financial performance, service quality, flexibility, and resource utilization. As a result, these conditions can encourage the competitiveness company as a proof of the company's ability to provide more value to its services than the competitors, and the value is beneficial to customers through higher education and training, ability to utilize technology, ability to innovate, infrastructure, institutions, financial market sophistication, and business sophistication. This finding is consistent with the research results of Wang (2008) and Rao (2012) that stated, entrepreneurship has a positive effect in business performance and the research result of Yang (2013) stated that organization performance has an effect on competitiveness. Thus, the findings of this research conform, support and confirm the results of previous research that entrepreneurship has a positive and significant indirect effect in competitiveness company with the mediation of organization performance, especially ferry shipping companies in Indonesia.

From the calculation results, the path coefficient of the indirect effect of innovation in competitiveness with the mediation of organization performance is 0.59 . While the $t_{\text {value }}$ score obtained is 5.04 , and the $t_{\text {table }}$ score at $\alpha=0.05$ is 1.97 . The score of $t_{\text {value }}>t_{\text {table, thus }} \mathrm{H}_{5}$ is accepted, which means innovation has a positive and significant indirect effect on competitiveness with the mediation of organization performance. The result of this research 
empirically proves that innovation has a positive and significant indirect effect on company competitiveness with the mediation of organization performance. This proves that innovation is important and determines the competitiveness of the company with the support of organization performance. This result is consistent with the direct effect of innovation on organization performance and organization performance on company competitiveness. When innovation as an individual action is directed toward generating, introducing or applying new and profitable findings at every level of the organization, and reflected in the exploration of opportunity, generativity, informative investigation, championing, and application, it can encourage the improvement of the organization performance as a company's ability to achieve target through competitiveness, financial performance, service quality, flexibility, and resource utilization. As a result, it can enhance the competitiveness of the company as a prove of the company's ability to deliver more value to its services than its competitors and bring value to customers through higher education and training, ability to utilize technology, ability to innovate, infrastructure, institutions, financial market sophistication, and business sophistication. This finding is consistent with the previous research result of Marques and Ferreira (2009), Gunday, et al. (2011), as well as Balan and Lindsay (2010) that stated innovation has a significant effect on organization performance as well as the research result of Yang (2013) that organization performance has an effect in competitiveness. Thus, the findings of this research conform, support and confirm the results of previous research that innovation has a positive and significant indirect effect on company competitiveness with the mediation of organization performance, especially ferry shipping companies in Indonesia.

\section{Conclusion}

There is a positive and significant direct effect of entrepreneurship on organization performance. There is a positive and significant direct effect of innovation on organization performance. There is a positive and significant 
direct effect of organization performance on the competitiveness of ferry shipping companies in Indonesia. There is a positive and significant indirect effect of entrepreneurship on company competitiveness mediated by organization performance. There is a positive and significant indirect effect of innovation on company competitiveness mediated by organization performance.

\section{References}

Affif, Faisal. 2012. Kepemimpinan \& Kewirausahaan Multi Talenta. Bandung: Asean Plan Consult Publishing House.

Atkinson, Helen \& Jackie Brander Brown. 2011. "Rethinking performance measures: assessing progress in UK hotels." International Journal of Contemporary Hospitality Magement. Vol. 13, No. 3, 128-135

Balan, Peter, and Noel Lindsay. 2010. Innovation Capability, Entrepreneurial Orientation and Performance in Australian Hotels: An Empirical Study, Queensland: CRC for Sustainable Tourism Pty Ltd .

Barney, J. B. and W. S. Hesterly. 2008. Strategic Management and Competitive Advantage: Concepts and Cases. New Jersey: Pearson Prentice Hall.

Chopra, S., dan P.Meindl. 2010. Supply Chain Management, Fifth Edition. England: Edinburgh Gate.

Gunawan, Herry. 2015. Pengantar Transportasi dan Logistik, Cetakan Kedua. Jakarta: Penerbit PT. Rajagrafindo Persada.

Gunday, et al., Gurhan, "Effects of Innovation Types on Firm Performance," International Journal of Production Economics, Volume 133, Issue 2, 2011, 662-676.

Hisrich, R., M. P. Peters, dan D. A. Shepherd. 2008.Entrepreueurship, SalembaEmpat.

Hutabarat, Jemsly dan MartaeniHuseini. 2012. Strategi: Pendekatan Komprehensif dan Terintegrasi. Jakarta: UI-Press.

Ireland, R. D., R. E. Hoskisson, and M. A. Hitt. 2011.The Management of Strategy: Concept and Cases, Mason, OH: South Western, Cengage Learning.

Kleysen, R., and Street, C.T. 2011. "Toward a multi-dimensional measure of individual innovative behavior", Journal of Intelectual Capital, Vol. 2, No. 3, 284-296.

Lis Lesmini S.H.,M.Si dan Rudi Purwanto S.T. 2016, "Ekonomi maritim \& sumber daya manusia Indonesia," Jurnal Manajemen Bisnis Transportasi dan Logistik, Vol.2, No.3 (2016).

Marques, Carla Susana, dan João Ferreira, "SME Innovative Capacity, Competitive Advantage and Performance in a 'Traditional' 
Industrial Region of Portugal," Journal of Technology Management Innovation, 2009, Volume 4, Issue 4, 53-68.

Martinez, M. C., \& Wolverton, M. 2009. Innovative Strategy Making in Higher Education. Charlotte: Infroamtion Age Publishing, Inc.

Masyhudzulhak, Jamil. 2014. Manajemen Strategi. Bengkulu: LembagaPengkajianSumberdaya (LP2S).

Minvielle, Etienne, et al.,2008. "Assessing organizational performance in intensive care units: A French experience", Journal of Critical Care, 23, 236-244.

Rao, M. V. K. Srinivasa. (2012). "The Impact of Entrepreneurial Orientation and Leadership Styles On Business Performance: A Study On Micro Small and Medium Enterprises." International Journal of Entrepreneurship \& Business Environment Perspectives, Vol. 1, No. 2, 111.

Robbins, S. P. and Judge, T.A. 2013. Organizational Behavior, New Jersey: Pearson Education, Inc.

Ross, S., Westerfield. R., and Jordan, B. 2008.Essentials of Corporate Finance. New York: McGraw-Hill Irwin.

Suryana, Yuyus dan Kartib Bayu.2010. Kewirausahaan, Pendekatan Karakteristik Wirausahawan Sukses, Kencana.

Wang, Catherine L. 2008. "Entrepreneurial Orientation, Learning Orientation, and Firm Performance."Paper, Brunel University Brunel Business School, Uxbridge, Middlesex UB8 3PH United Kingdom, 2008, 1-25.

Watkins, A., and A. Verma. (2007). "Higher education, competitiveness, and innovation capability, in south and east asia: A benchmarking exercise," Science, Technology and Innovation Program Education Department Human Development Network.

White, M. A. and G. D. Bruton. 2007. The Management of Technology and Innovation: A Strategic Approach, Mason, OH: Thomson Higher Education.

Yang, C. et al. 2013. "The effect of green supply chain management on green performance and firm competitiveness in the context of container shipping in Taiwan," Transportation Research Part E: Logistics and Transportation Review55, 55-73. 